\title{
Factors Associated with Nutritional Status of Under Five Children in Rupandehi District of Nepal
}

\author{
${ }^{1}$ Dilaram Acharya, ${ }^{1}$ Salila Gautam, ${ }^{2}$ Hari Prasad Kaphle, ${ }^{3}$ Nirmala Naupane \\ ${ }^{1}$ Sanjeevani College of Medical Science, Rupandehi, Nepal \\ ${ }^{2}$ School of Health and Allied Sciences, Pokhara University, Kaski, Nepal \\ ${ }^{3}$ Masood College of Nursing, Rajiv Gandhi University of Health Sciences, Bangalore- 564001, Karnataka.
}

\begin{abstract}
Childhood is a time of active growth in terms of physical size, mental, emotional and psychological development. Normal growth is dependent on adequate nutrition and encompasses major transformations from birth to adulthood. Socio-economic status and behaviors of family members, environmental factors are other determinants of nutritional status of under five year children. This research was conducted to assess the factors associated with nutritional status of under five year children in Rupandehi District of Nepal. This was a community based Cross-sectional study. It was conducted in Rupandehi. Two hundred ninety two children were selected using proportionate random sampling technique. For collecting the data, selected households were visited by enumerators for two months from January to February 2008. Data were analyzed using SPSS version 12. The proportion of the participants was $51.7 \%$ male and $48.7 \%$ female. Nearly half of the children (45.9\%) of the children aged 3659 months were under weight according to Indian Academy of Pediatrics (NCHS/WHO standard). Fifty percent of the children born to illiterate mothers were found underweight. Majority of the children (65\%) were found stunted according to Waterlow's classification. More than the half the children (57.75\%) were underweight who were born by mother less than 18 years of age where as $75 \%$ were underweight born by mother aged above 35 years of age. However the association between age of the mother at the birth of the child and nutritional status is not statistically significant. More than half of the children were found underweight and Nearly $2 / 3^{\text {rd }}$ of the children were found stunted. To get better nutritional status of children, greater emphasis should be given to under five years children with community based awareness programs to mother and care givers.
\end{abstract}

Key words: Height-for-age, weight-for-age, Malnutrition, Waterlow's classification

Corresponding address: Dilaram Acharya, Department of Public Health, Sanjeevani College of Medical Science, Butwal, Rupandehi, Nepal. E-mail: dilaramacharya123@gmail.com.

\section{INTRODUCTION}

Malnutrition remains a serious obstacle to child survival, growth and development in Nepal. Prevalence of malnutrition among under five children is high with $48.6 \%$ in the country. Protein-energy malnutrition (PEM) and micronutrient deficiency are most common types of malnutrition. ${ }^{1}$ Undernutrition remains as a serious problem in under-developed countries, resulting from consumption of poor diet over a long period of time. ${ }^{2}$

Protein energy malnutrition has been a common health problem of the third world countries Stunting and wasting are common patterns of under-nutrition in children. In children, acute nutritional deficit and/or disease (such as diarrhoea) produce wasting, characterized by a reduction in weight-forheight or arm circumference, or both. Prolonged nutritional deficit and/or disease result in stunting, characterized by a reduction in height-for-age. Wasting and stunting are associated with functional consequences. ${ }^{3,4,5,6}$ Nutritional assessment involves anthropometric measurement, biochemical tests, clinical observation, functional assessment, dietary survey, ecological study and study of vital statistics. However, individual nutritional status has been reported to vary on the basis of person's living conditions, available food supply, health and socio-economic status. ${ }^{7,89}$ WHO estimates that 175 million children in the developing world are malnourished as indicated by low weight-for-age and 230 million are stunted as indicated by height for age. It is recognized that the majority of deaths among children in the developing world are associated with malnutrition. ${ }^{10}$

As of the Nepal Demographic and Health Survey 2006, (NDHS) $49 \%$ of children below 5 years of age are affected by stunting. The survey also showed that $39 \%$ of the children are underweight and $13 \%$ of the children below 5 years are wasted. Malnutrition is not evenly distributed throughout Nepal; it varies both ecologically and regionally. Stunting, underweight and wasting are more common in mid and far west hills and mountain areas than other part of the country. All three indicators are poor in the central Terai. ${ }^{11}$

Several initiatives such as Growth monitoring, vitamin A distribution, deworming porgrammes have been taken to reduce the impact of nutritional deficiency and promotion of health of under five years children in Nepal. Still two types of programmes - short-term, disease-specific initiatives and more general programmes of primary health care - have contributed to the decline in mortality. Both programmes can contribute substantially to strengthen the health system and enabling households and communities to improve their health care. For completing the unfinished agenda of improving child health globally, community based mass awareness programmes, identification of risk factors among those community and implementation of need based programmes are needed. On the other hand, greater emphasis should be placed on modifying those household behaviors that are not 
dependent on the performance of health systems. Therefore, evidence based information is needed to modify the adverse behavioral factors of households and communities and improve the nutritional status of under year five children.

\section{METHODS}

A community based descriptive cross-sectional study was conducted during January to February 2008 in Rupandehi district of Nepal. Khadawa Bangai Village Development Committee of Rupandehi district was selected purposely for the study. Total population under five year children population of this VDC was 9165. Children of under five years of the same VDC constituted the sample unit whereas mother or care givers of these children were the respondents. The sample size of 292 children was determined using $49 \%$ prevalence of stunted children of Nepal. ${ }^{11}$

Total numbers of under five year children were listed wardwise and selected proportionately. Enumerators visited listed household and interviewed to mothers or caregivers of children by using pre-tested structured interview schedule for data collection. Measuring tape for height and weighing machine for weight were used for anthropometric measurements. Data were analyzed by using SPSS software and statistical tests were applied for validation of the information. Written approval was obtained from District Public Health Office, Rupandehi. Participants were informed about objective and importance of the study and verbal consent was taken from them before data collection.

\section{RESULTS}

Out of 292 under five years children, more than two third $(71.6 \%)$ of the children were below three years and remaining were between 37 to 59 months. There were $51.7 \%$ male and remaining female. Most of the children were belonging to Hindu only $5 \%$ were Muslims. Majority of the children were belong to nuclear family $(58.2 \%)$ and large number of the respondents were belonging to agricultural works (90\%) followed by business (4\%), labor (4\%) and service (2\%). Nearly half of mothers were illiterate $(47.9 \%)$ followed by $18.2 \%$ non-formal education, $17.1 \%$ primary level, $16.7 \%$ secondary level and no one above intermediate level.

According to Indian Academy of Pediatric classification of nutritional status nearly half of the children (48.3\%) had normal nutritional status followed by $27.7 \%$ grade I PEM, $18.2 \%$ grade II PEM and only $1.4 \%$ severely malnourished.

Table 1: Nutritional status of the children (Weight for age IAP classification)*

\begin{tabular}{|l|c|c|}
\hline $\begin{array}{l}\text { Nutritional status } \\
\text { Normal }(\geq 80 \%)\end{array}$ & $\begin{array}{c}\text { Frequency } \\
141\end{array}$ & $\begin{array}{c}\text { Percentage } \\
48.3\end{array}$ \\
\hline Grade I PEM $(71-80 \%)$ & 81 & 27.7 \\
\hline Grade II PEM $(61-70 \%)$ & 53 & 18.3 \\
\hline Grade III PEM $(51-60 \%)$ & 15 & 4.5 \\
\hline Grade IV PEM $(\leq 50 \%)$ & 4 & 1.4 \\
Total & 292 & 100 \\
\hline
\end{tabular}

*Weight for Age calculated according to IAP (Indian Academic of Pediatrics and NCHS standards)
According to the Gomez classification $17.8 \%$ children were found normal followed by $42.5 \%$ were mild under nourished, $33.9 \%$ moderately undernourished and $5.8 \%$ were severely malnourished.

Table 2: Nutritional status of the children (weight for age Gomez classification) *

\begin{tabular}{|l|c|c|}
\hline Nutritional status & Frequency & Percentage \\
\hline Normal $(\geq 90 \%$ of Median) & 52 & 17.8 \\
\hline $\begin{array}{l}\text { Mild Under nutrition (Gr. I) } \\
\text { (76-90\% of Median) }\end{array}$ & 124 & 42.5 \\
\hline $\begin{array}{l}\text { Moderate Under nutrition (Gr. } \\
\text { II) (61-75\% of Median) }\end{array}$ & 99 & 33.9 \\
\hline $\begin{array}{l}\text { Severe Under-nutrition (Gr. } \\
\text { III) ( } \leq 60 \% \text { of Median) }\end{array}$ & 17 & 5.8 \\
\hline Total & 292 & 100 \\
\hline
\end{tabular}

*Weight for age calculated according to Gomez malnutrition Classification (NCHS/WHO as standard)

Nearly half $(45.2 \%)$ of the children were found stunted followed by $14.7 \%$ moderately impaired and $5.1 \%$ were severely impaired. About one third (34.9\%) were normal as per height -for- age.

Table 3: Nutritional status of the children: height-for-age*

\begin{tabular}{|l|c|c|}
\hline Nutritional status & Frequency & Percentage \\
\hline Normal (>95\%) & 102 & 34.9 \\
\hline Mild Impaired (87.5\%-95\%) & 132 & 45.2 \\
\hline Moderate Impaired (80\%-87.5\%) & 43 & 14.7 \\
\hline Severely Impaired (<80\%) & 15 & 5.1 \\
\hline Total & 292 & 100.0 \\
\hline
\end{tabular}

*Height for age according to Waterlow's classification and NCHS standards

According to IAP classification of malnutrition taking NCHS1977/WHO weight by age median (WAM) as standard; the study found that $48.29 \%$ of children were normal. The highest $(41.67 \%)$ of Grade I PEM was found in children whose mothers' education was high school level. The Grade IV PEM was the highest $(2.14 \%)$ in the children of illiterate mothers. and there was not found Grade IV PEM in the children whose mother had education level primary or above.

Table 4: Nutritional status of children by education of the mother (IAP*)

\begin{tabular}{|c|c|c|c|c|c|c|}
\hline \multirow[b]{2}{*}{$\begin{array}{l}\text { Education of the } \\
\text { mother }\end{array}$} & \multicolumn{5}{|c|}{ IAP classification of Nutritional status } & \multirow[b]{2}{*}{ Total } \\
\hline & $\begin{array}{l}>80 \% \\
\text { Normal }\end{array}$ & $\begin{array}{l}\text { 71-80\% } \\
\text { "Grade } \\
\text { I PEM" }\end{array}$ & $\begin{array}{l}\text { 61-70\% } \\
\text { "Grade } \\
\text { II PEM" }\end{array}$ & \begin{tabular}{|l|}
$51-60 \%$ \\
"Grade \\
III PEM"
\end{tabular} & $\begin{array}{l}\leq 50 \% \text { “ } \\
\text { Grade IV } \\
\text { PEM" }\end{array}$ & \\
\hline Illiterate & 50 & 25 & 20 & 4.29 & 2.14 & 47.9 \\
\hline Non formal education & 49.06 & 30.19 & 9.43 & 9.43 & 1.89 & 18.2 \\
\hline Primary & 44.0 & 28.0 & 24.0 & 2.0 & 0.0 & 17.1 \\
\hline Middle high school & 48.65 & 29.73 & 16.22 & 2.7 & 0.0 & 12.7 \\
\hline High school & 41.67 & 41.67 & 16.67 & 0.0 & 0.0 & 4.1 \\
\hline Total & 48.29 & 27.74 & 18.15 & 4.45 & 1.37 & 100 \\
\hline
\end{tabular}

parentheses shown in percentage

Nutritional status of children by age showed that nearly fifty 
percent $(42.31 \%)$ of the children were underweight in $0-5$ month's age group where as $55.1 \%$ and $54.05 \%$ children of age group 12-23 months and 24-35 respectively found to be under weight.

Table 5: Nutritional Status of Children by Age

\begin{tabular}{|c|c|c|c|c|c|c|}
\hline \multirow[b]{2}{*}{$\begin{array}{l}\text { Age of the } \\
\text { child in } \\
\text { months }\end{array}$} & \multicolumn{5}{|c|}{ Weight for age(IAP) classification } & \multirow[b]{2}{*}{ Total } \\
\hline & $\begin{array}{l}>80 \% \\
\text { Normal }\end{array}$ & \begin{tabular}{|c|}
$71-80 \%$ \\
Grade I \\
PEM
\end{tabular} & \begin{tabular}{|c}
$61-70 \%$ \\
Grade II \\
PEM
\end{tabular} & \begin{tabular}{|c|}
$51-60 \%$ \\
Grade III \\
PEM \\
\end{tabular} & $\begin{array}{c}\leq 50 \% \\
\text { Grade IV } \\
\text { PEM }\end{array}$ & \\
\hline $0-5$ months & 57.69 & 11.54 & 15.38 & 7.69 & 7.69 & 8.9 \\
\hline 6-11 months & 54.34 & 13.04 & 32.61 & 0.0 & 0.0 & 15.8 \\
\hline $12-23$ months & 44.9 & 28.57 & 12.24 & 12.24 & 2.04 & 16.8 \\
\hline $24-35$ months & 45.95 & 37.84 & 10.81 & 2.7 & 2.7 & 12.7 \\
\hline 36-47 months & 45.09 & 33.33 & 21.57 & 0.0 & 0.0 & 17.5 \\
\hline $48-59$ months & 46.99 & 32.52 & 15.66 & 4.82 & 0.0 & 28.4 \\
\hline Total & 48.29 & 27.74 & 18.15 & 4.45 & 1.37 & 100 \\
\hline
\end{tabular}

Majority of the children (57.75\%) were underweight according to weight for age (IAP) classification who were born to mothers less than 18 years of age whereas $75 \%$ were underweight born to mother aged above 35 years and more than the half of the children were normal $(55.66 \%)$ who were born to mothers aged 18-20 years. However the association between age of the mother at the birth of the children and nutritional status of children is not statistically significant.

Table 6: Nutritional status of the children by age of the mother at the birth of the child

\begin{tabular}{|l|c|c|c|}
\hline \multirow{2}{*}{ Age of mother } & \multicolumn{2}{|c|}{ Nutritional status } & \multirow{2}{*}{ Total } \\
\cline { 2 - 3 } & Normal & Underweight & \\
\hline$<18$ years & $30(42.25)$ & $41(57.75)$ & 71 \\
\hline $18-20$ years & $50(55.56)$ & $40(44.44)$ & 90 \\
\hline $20-35$ years & $60(47.24)$ & $67(52.76)$ & 127 \\
\hline$>35$ years & $1(25)$ & $3(75)$ & 4 \\
\hline Total & 141 & 151 & 292 \\
\hline \multicolumn{2}{|c|}{$\chi^{2}$ cal $=4.11, \mathrm{df}=4, \chi^{2}$ tab $=9.49$ (not significant) } \\
\hline
\end{tabular}

* Figures in parentheses shown in percentage

\section{DISCUSSION}

NDHS 2006 showed that infant mortality has declined over last 15-year period from 82 to 48 deaths per 1,000 live births. Under-five mortality has gone down from 117 to 61 deaths per 1,000 live births. The corresponding declines in neonatal and post neonatal mortality over the 15 -year period are 33 and 55 per thousand respectively. ${ }^{11}$

There was similar trend of sex-wise distribution of the children. Most of the children were from Hindu and few were from Muslim. Majority of the children were from schedule caste followed by equivalent number of children from general and backward caste. Majority of the children were from nuclear family. Very few mothers were engaged in paid jobs outside home. It is clear from the study that forty eight percent of the mothers were illiterate. The nutritional status of the children was affected by education level of the mother of the children since fifty percent of the children of illiterate mother had some form of the malnutrition.
An observational study conducted on nutritional status of under five years of children in Jirel community in Jiri VDC, Dolakha district of Nepal to assess the nutritional status of Jirel children of age group 12 months to 60 months, It was found that $64 \%$ had mild to moderate malnutrition, 37 children were normal and no one was severely malnourished. ${ }^{9}$ This study shows that more than fifty percent children were malnourished according to Indian Academic of paediatrics classification (weight for age) including 27.7\% Grade I PEM followed by $18.2 \%$ grade II PEM and $1.4 \%$ severely malnourished. This study differs with the study done on Prevalence and Predictors of Underweight, Stunting and Wasting in Under-Five Children in Dhankuta District of Nepal found that Prevalence of underweight and stunting in the study VDC was $37 \%$ and $27 \%$ respectively. ${ }^{13}$

According to Waterlow's classification, majority of the children $(65.1 \%)$ were stunted in the study. On contrary, this differs with study done in Jiri, eastern hilly region of Nepal to assess the nutritional status under five years children where more than $2 / 3^{\text {rd }}$ (71\%) were normal and remaining were stunted. ${ }^{9}$

The study shows more than forty two percent of children were underweight in the age group 0-5 months where as more than fifty percent children were under-weight in 12-35 months of age group. Findings of the this study are similar to the study on Rapid assessment of nutritional status and dietary pattern in a municipal area of North Bengal of India where Prevalence of malnutrition was observed to be $62.97 \%$ and prevalence of severe degree of malnutrition was $6.65 \%$, more so amongst $12-23$ months of age and amongst females. ${ }^{12}$

Nearly half of the children (41.67\%) Grade I PEM was found in children whose mothers' education was high school level. The Grade IV PEM was the highest (2.14\%) in the children born to illiterate mothers and there was not found Grade IV PEM in the children whose mother had education level primary or above. Mother's educational status wasn't found significant to predict undernutrition. But some of the studies carried out in North America and Africa found significant association between them. ${ }^{14}$ Similarly the study conducted in under five years children to assess the nutritional status at Oranfe, a semi-rural community in Ife East Local Government Area of Osun state, Nigeria, found that mothers' educational level, age, parity, types of family and children's immunization status were some of the key determinants of nutritional status of U5 children. ${ }^{12}$

This study shows more than fifty percent (57.75\%) were underweight according to weight for age (IAP) classification who were born to mothers less than 18 years of age whereas $3 / 4^{\text {th }}$ were underweight born to mother aged above 35 years. However the association between age of the mother at the birth of the children and nutritional status of was not statistically significant at 5\% level of significance. On contrary to this, the study conducted in Dhankuta District of Nepal found maternal age more than 35 years at pregnancy, was a risk factor for stunting and underweight in children at $10 \%$ level of significance. ${ }^{13}$ 


\section{CONCLUSION}

The study shows high prevalence of the underweight and stunted children in the rural community requires National Nutritional Programme should monitor the growth of the under-five children in terms of both weight and height. The results also confirmed that mothers' educational level, age and age of children are some of the key determinants of nutritional status of under five years' children. Maternal age at birth of children as found determining the nutritional status of children, Community based awareness programmes regarding consequence of early and late marriage should be launched. Mother's education also plays a significant role to improve nutritional status of children so girls' education should intensify nationally.

\section{ACKNOWLEDGEMENT}

We would like to express our sincere gratitude to Dr. Varidmala Jain, Assistant Professor and Dr. Vinita Dayal, Dean Faculty of Health and Medical Sciences, Sam Higginbottom Institute of Agriculture, Technology \& Sciences, Allahabad, India for their academic guidance. We would regard to all the respondents of this study for their kind cooperation and support during the study.

\section{REFERENCES}

1. Ministry of Health and Population (Nepal), Department of Health Services. Annual Report 2005/06; 2007.

2. Awan JA. Food and Nutrition. Delhi: Moon Publisher; 1997.

3. Mitchell HS. Nutrition in relation to stature. J. Am. Dietet. Assoc. 1962; 40:521-25.

4. Sinta SB, Zaheer M. Anthropometric measurements in rural school children. JR Soc Health. 1990; 11:184-86.

5. Williams SR. Essential of Nutrition and Diet Therapy. Seventh Ed. St Louis, Baltimore, London; 1994.

6. Government of Pakistan. National Nutrition Survey, 1985-87. Report, Islamabad GoP, Nutrition Division. National Institute of Health; 1988.

7. Waterlow JC, Buzina R, Keller W, Lane JM, Nichaman MZ, Tanner JM. The presentation and use of height and weight data for comparing the nutritional status of groups of children under the age of 10 years. Bulletin WHO.1977; 55(4):489-498.

8. Waterlow JC. Classification and definition of protein calorie malnutrition. BMJ. 1972; 3:566-569.

9. Chapagain RH, Adhikari AP, Dahal R, Subedi J, Blengero J, Williams BS, Towne B. A Study on Nutritional Status of under five Jirel Children of Eastern Nepal. Journal of Nepal Health Research Council. October 2005; 3:2.

10. Ray SK, Biswas AB, Gupta SD. Rapid Assessment of nutritional status and dietary pattern in a municipal area. Indian Journal of Community Medicine. 2000 Jan-Mar; 25(1):14-18.

11. Ministry of Health and Population, New ERA, Macro International Inc. Nepal demographic and health survey $2006 ; 2007$.

12. Ojofeitimi EO, Owolabi OO, Aderonmu A, Esimai AO, Olasanmi SO. A study on under five nutritional status and its determinants in a semi-rural community of Ile-Ife, Osun State, Nigeria. Nutrition Health. 2003;17(1):21-27

13. Sapkota VP, Gurung CK. Prevalence and Predictors of Underweight, Stunting and Wasting in Under-Five Children. J Nepal Health Res Counc. 2009 Oct; 7(15):120-26.

14. Antonieta M, Helena M. Mother's Ability of childcare and child malnutrition. Rev Saude Publica. 2002; 36(2):188-97. 